\title{
Music by František Škvor for the Karol Plicka's Film The Earth Sings - the Beginning of Slovak National Music?
}

Some Remarks on the Origin and Importance of Škvor's Music for Plicka's Film Zem spieva

\author{
Branko Ladič / branko.ladic@gmail.com \\ Department of Musicology, Comenius University, Bratislava, SK
}

\begin{abstract}
Karol Plicka (1894-1987), musicologist, etnographer, photographer, violinist and teacher devoted the main part of his professional life to Slovakia. During the interwar period he became the most significant slovak foklorist. The invention of sound film inspired him to make a film as an artefact with Slovak ethnographic subject matter, and the result was the first Slovak fulllength film The Earth Sings (1930-1933).

The aim of the film makers was to present images from the Slovak countryside from spring to autumn. Situations presenting the life of the common people, which dominate the film, offer the opportunity to present folklore: ceremonies, dances, children's games, and of course music. Plicka regarded music as exceptionally important in the film. His original aim was to add original folklore sung and played directly by the film protagonists, but that turned out to be technically impossible, in the end it was necessary to write an original film score, and he chose František Škvor, the composer and conductor of the National Theatre in Prague, to fulfil the task. Škvor's music contains originally composed music, music inspired by slovak folklore melodies and concrete quotations of slovak folk music.

In my contribution I want to focus the ideological basic of the film, which I find very important for the whole conception of Škvor's score, and concrete musical elements, which was used by the composer. Of course, I want to focus the significance of the Škvor's music for the development of the Slovak national music, which was then, at the beginning of 1930s, very actual problem of Slovak musical life.
\end{abstract}

\section{Keywords}

film music, editing, folklore inspiration, motivic material, German tradition, Russian romantic music 
Karel Plicka's film Zem spieva (The Earth Sings) belongs undoubtely to the Chefs d'oeuvre of Slovak cinematography, even with its ideological intentions, form, editing, and last, but not least with music we could rank it to the prominent Works of the genre of artistic documentary films at all.

The film was developed at the beginning of the 1930s, which was a very important period for the establishment of Slovak national music. In this paper I want to focus briefly on the inspiration, formation and importance of Škvor's film music for the subsequent development of Slovak music.

Under the new conditions in the new regime after the birth of the Czechoslovak Republic a demand for an independent and peculiar music culture was felt. The strongest professional compositional personalities, which arose from the otherwise amateurish provincional Slovak cultural life - Ján Levoslav Bella (1843-1936), Mikuláš Schneider Trnavský (1881-1958), Frico Kafenda (1883-1963), were strongly influenced by the dominant German musical culture, and although they were more or less devoted to Slovak folk music (theoretically or practically), only the younger of the abovementioned composers were often criticised by provincial artistic circles for their not-understandable modernity. ${ }^{1}$ Under these relatively problematic conditions, the main task for the youngest generation of composers remained the creation of an independent Slovak music culture. This generation was strongly supported by prominent Czech artistic and musical circles - by the Composer Vítězslav Novák (1870-1949), who was also the mentor and teacher of Alexander Moyzes (1906-1984), Eugen Suchoň (1908-1993) and Ján Cikker (1911-1989), or by the influetial pesonality of Dobroslav Orel (1870-1942), Professor of the Musicology at Comenius University in Bratislava (in the period of 1921-1938). Although Orel advocated for a sense of Czechoslovak continuity with the line of composers Smetana - Bella - Novák (which appears for us now as truly artificial), ${ }^{2}$ it was ultimately the modern tendencies of predominantly French origin, combined with a new way of using Slovak folk music elements, which led to the establishment of an independent and widely accepted Slovak national music durig 1930s.

Plicka's film, with its very impressive musical section, was born shortly before the arrival of the young generation Moyzes - Suchoň - Cikker. The film's musical conception was developed relatively independently from the later Slovak trends - in Škvor's music the main inspiration of the elaboration of folk music elements was based on the Russian romantic tradition.

Karel (Karol) Plicka (1894-1987) was born in Vienna (his family came from Česká Třebová, where he spent part of his childhood), he was a member of the boys' choir

1 In 1912 Milan Lichard (1853-1935), then widely accepted as a strong personality in musical life, hardly criticised the moderity of the song-cycle Slzy a úsmery (Tears and Smiles) by Mikuláš Schneider Trnavský, For more informations see HRČKOVÁ, Nad'a. Tradícia, modernost' a slovenská hudobná kultúra (Tradition, Modernity and Slovak musical culture), Bratislava, Litera, 1996, p. 19-27, or KRESÁNEK, Jozef. Slovenská hudba na rázcestí. Slovenská hudba, Bratislava, 1967.

2 On the problem of Bella's reception in interwar period see HRČKOVÁ, Nad'a. Tradícia, modernost’ a slovenská hudobná kultúra, op. cit., p. 116-120. 
Wiener Sängerknaben, later of the choir of the Vienna Court Opera. Plicka called himself "a master of nine crafts"; following the will of his parents he became a teacher, but he was also a violinist, photographer, ethnographer and musicologist. He was also interested in a new medium of the time - the film, which became his further vocation. A great part of his professional life Plicka devoted to Slovakia; in the interwar period he was the most significant Slovak folklorist. In the period of 1924-1939 he worked for the Matica slovenská (Slovak Society) and he was collecting Slovak folk songs, while using also photography and a film camera - during the Year 1926 Plicka made two short silent documentary films - Pod Tatrami (Under the Tatras) and Čičmany I. Both films was not more as pure etnologic documents, but we could consider them as studies for the following projects, which was enabled by generous presidential support (1928). During the same Year came into existence the full-lenght silent Film Za slovenským liudom (To the Slovak People), which was premiered in Prague and Košice in september 1928. The film was given even during The International Congress for The Folk Art (7. - 13. 10. 1928 in Prague). It is very interesting, that for this ocassion the young composer Jaroslav Ježek (1906-1942) in collaboration with Plicka wrote accidental music based on themes of Slovak folk songs, it was also really composed film music. Film Za slovenským ludom is now lost, but some scenes ofit contains the next Plickas film Po horách, po dolách (Through the Mountains, through the Valleys), which was shot during the Year 1929 und succesfully premiered in Prague (dec. 1929) and Turč. Sv. Martin (march 1930). By making copy of the film im 1931, Plicka replaced some „too descriptive scenes“ with the scenes of more artistic and poetic form. Through these changes came to relative strong advance in the conception of the film, we could also speak about the second Version of the film, which was premiered in Aprile 1931 in Bratislava and in such form represented at Biennale in Venice in 1932. Through the aforementioned matter we could see Plickas ambition and advance in the conception of film production from pure documentary film towards the artistic creation.

But it was the invention of sound film, which could full up Plickas artistic ambitions and inspired him to make a film as an artwork with Slovak ethnographic subject matter. The result was the first Slovak full-length film The Earth Sings. Officially it was produced by Matica slovenská. Its "Slovak character" from the cultural and ideological perspective is undeniable, but the creative team was wholly Czech - Karel Plicka (1894-1987), Alexander Hackenschmied (1907-2004), responsible for editing, and František Škvor (1898-1970), the author of the music. Two-thirds of production costs were covered by the Czech producer Ladislav Kolda (1903-1983), and the film was produced under the auspices of the president of the republic Tomáš Garrigue Masaryk. ${ }^{3}$

The production proceeded from the spring 1930 to the summer 1933, being cut in the meantime from August 1932.

The aim of the film makers was to present images from the Slovak countryside from spring to autumn. The view of Prague as the capital of the country followed by the train journey to Slovakia were the prologue of the film. It was probably in 1939, after the

3 Compare LEXMANN, Juraj. Slovenská filmová hudba 1896-1996 (Slovak Film Music 1896-1996), Bratislava: Ústav hudobnej vedy SAV - ASCO Art\&Science, 1996, p. 40. 
dissolution of Czechoslovakia, when these film shots were replaced by a montage from Bratislava street life. Then the main part of the film follows: situations presenting the life of the common people, which dominate the film and offer the opportunity to present folklore: ceremonies, dances, children's games, and of course music. Plicka regarded music as exceptionally important in the film. His original aim was to add original folklore sung and played directly by the film protagonists, but that turned out to be technically impossible, as Plicka was recording the film in difficult conditions - unbelievably difficult from the present perspective, for he was shooting on location on his own, with no film crew. ) In the end it was necessary to write an original film score (Plicka used only 6'25" of autentic music from the recording, which was made by him for the firma Pathé in 1929, the rest - 58'43" is Škvor's composition).

Miloš Ruppeldt (1881-1943), then one of the most significant personality of Slovak musical life, suggested, that the music should be written by a Slovak composer, but it was not realized through the technical and organisatory reasons - first of all, the presence of the composer during the whole production and editinig process in Prague was necessary.

The specific name was not mentioned - and the choice was truly problematic. With the exclusion of the name of J. L. Bella (then short before his 90th anniversary), the composers like M. Schneider Trnavský or F. Kafenda were only a little acceptable for Plicka because of their tendencies towards Western, especially German music traditions (as we have above mentioned). Among the young composers there was only A. Moyzes, who completed his studies with V. Novák in Prague. In the end Plicka chose František Škvor, the composer and conductor of the National Theatre in Prague (1923-1960), to fulfil the task.

F. Škvor was a son of the violist of the Orchestra of National Theatre in Prague (born in Varaždinske Toplice in 1898). After his leaving examination on Gymnasium in Prague and 3 years millitary service studied jurisprudence at Charles University, in the same time studied privately composition with V. Novák (piano with A. Mikeš). Between 1923-1960 he was conductor in The National Theatre in Prague. He was an outstanding expert of Russian music. Škvor as a composer had the tendency to the so-called slavic „cantabile-style“ supported by strong inspiration from folk music, and even perfect technical realisations of his scores concerning instrumentation and form. Plicka knew Škvor since 1919 (he was then pianist in the Choir conducted by Plicka), he knew his ideas, ideological tendencies and Oeuvres too: „Nyni nastala nejužši spolupráce se skladatelem F. Škvorem, s nimž mne již po léta sbližoval ryze slovanský ráz jeho hudby. Jeho melodika, napojená ryzi hudebnosti východoslovanskou a prožitím slovenské lidové pisně, zdála se mi dávno předurčenou k hudebnimu vyjádřeni slovenské duše. Výsledek mi to potvrdzuje."4

Plicka shared with Škvor a common interest in Eastern Slovak folk song. This became an important inspirational component influencing the total tone of Škvor's composition, in spite of the fact that majority of the film scenes were shot in Central Slovakia. This

4 "Now the closest collaboration with the composer Škvor began. For many years I felt an affinity with the purely slavic character of his music. His melodies, full of east-slavic musicality and understanding of slovak folk song, appeared to me as predestined to express the slovak soul musically. And the results confirm it". (Světozor, vol. 32, 10. 8. 1933). 
apparent contradiction yielded to artistic stylization, made by Plicka thanks to his sound knowledge of Slovak folk song (adequate to the research of the time). The use of Eastern Slovak folk song involved also an ideological dimension - according to both Plicka and Škvor it was closest to Ukrainian and Russian folk music; they strived to demonstrate the Old-Slavonic, "Pan-Slavic" basis of the Slovak folklore. From the geographical aspect it appeares to be a well-grounded opinion, even if actual relations used to be much more complicated. Plicka and Škvor considered the fourth descending jumps derivated from the so-called hypo-tonality ${ }^{5}$ in the conclusions of the songs an obvious relation to Russian folk song, for which such interval devices are characteristic, too (in a different tonal context, as far as we know).

Even today we cannot refute completely the reflection that Slavic music shares a common basis and its residues are present in various Slavic folk cultures. ${ }^{6}$ On the other hand the totally different cultural development and trivial contact with Russian ambience during the major part of the development of both folk cultures resulted in extensive differences in melody structure and tonality. During the development of the so-called NewHungarian song since the $19^{\text {th }}$ century it was namely the territory of the present Eastern Slovakia which was exposed to significant influence of this "music revolution", as Bartók called it, ${ }^{7}$ which had its cultural and social reasons (therefore it is the folklore from the Central Slovakia, the region in which the highest number of film scenes were shot, which used to be designated as more original and more typical one). At the same time it must be noted that the Eastern-Slovak song, or Slovak song as such, displays a high degree of affinity with Ukrainian song, or Western-Ukrainian song, or Ruthenian one (due to ideological reasons this term does not appear in the older literature). Here Bartók's opinion is also interesting, who considered the Ukrainian (or Ruthenian) "kolomyjka" one of the basic inspirational sources for the New-Hungarian song. ${ }^{8}$ The endeavour to point to the "Pan-Slavic" character of the Slovak folk music represented something additional to Plicka and Škvor, as they both came from the anti-Habsburg Russophile tradition of many Czech intellectuals of the $19^{\text {th }}$ century (Although we have not any concrete mention in this sense by Plicka, we can suppose it with regard to the whole social climate in Czech lands in 19th and beginnings of 20th century ). This tradition and an idea of Slavic solidarity did not cease to exist after the establishment of Czechoslovakia. Although new political and social conditions in the ČSR and Soviet Union were totally different, and due to political and ideological reasons the relations between the countries were not trouble-free (compare the activity of Czechoslovak Leagues during the Russian

5 Compare ELSCHEK, Oskár - ELSCHEKOVÁ, Alica. Úvod do štúdia slovenskej ludovej hudby (Introduction to study of Slovak folk music). Bratislava : Národné osvetové centrum, 1996, p. 155.

$6 \quad$ For this subject compare KRESÁNEK, Jozef. Slovenská ludová pieseñ so stanoviska hudobného (Slovak Folk Song from the Musical Standpoint). Bratislava, Slovenská akadémia vied a umení, 1951) p. 188-194.

7 Literally: "music revolution of Hungarian village"; compare KRESÁNEK, Jozef. Slovenská ludová pieseñ so stanoviska hudobného, op. cit., p. 238 and URBANCOVÁ, Hana. Novouhorský stúl v slovenskej hudobnej kultúre a procesy sebaidentifikácie (New-Hungarian Style in Slovak Music and the Processes of Self-identification).In SLÁDEK, Kamil - Škvarna, Dušan (eds.). Hladanie novej podoby strednej Európy (The Quest for a New Semblance of the Central Europe). Bratislava, Prešov: Centrum pre európsku politiku, 2005, p. 221-231.

KRESÁNEK, Jozef. Slovenská l’udová pieseñ so stanoviska hudobného, op. cit., p. 239. 
revolution, beside others), the "Panslavic" position was still alive, especially due to the endeavour to delineate itself against the strong German element, and in the Slovak conditions towards the Hungarian element, in the republic. The effort to approach the Russian folklore domain is obvious also in the film segments with religious themes - in a Greek Catholic ritual of blessing the food and by an Orthodox procession. (Both confessions intermingle and blend in the film into a certain, we may say artificial "Eastern ritual”.) For these film segments Škvor found an extremely apt and immensely "Russian" expression - Plicka himself spoke about the relation of these music segments with Mussorgsky's music from Boris Godunov?.

\section{Example 1}

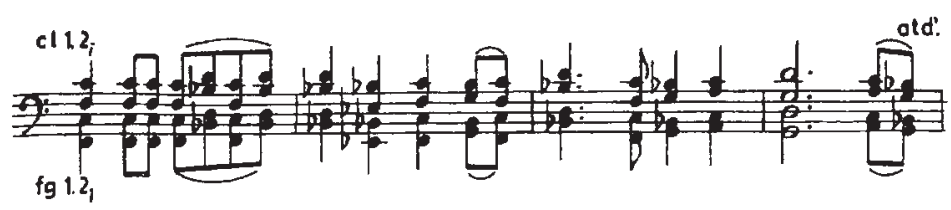

In Škvor's composition the way of handling the folk material is obviously similar to that of the Mighty Handful, as Russian composers in the 1860s had already created the way of embedding the modal melody into the harmonic frame. From the viewpoint of orchestration Škvor uses the devices resembling the music of Rimsky-Korsakov, mainly in the sections where he arranges the specific folk material, or in the music of a religious character (the abovementioned relations to the music from the opera Boris Godunov).

The folklore material consists of 28 folk songs, two of which are (or Plicka considered them as) as hutsul, i.e. Ruthenian (tunes Nos. 6 and 7). The degree of application of particular tunes is quite different in different film segments - from harmonization and orchestration of songs to the composition of original music inspired by a folk melody. The tune No. 8 may serve as an example, as its task is to characterize the "old" Slovakia:

\section{Example 2}

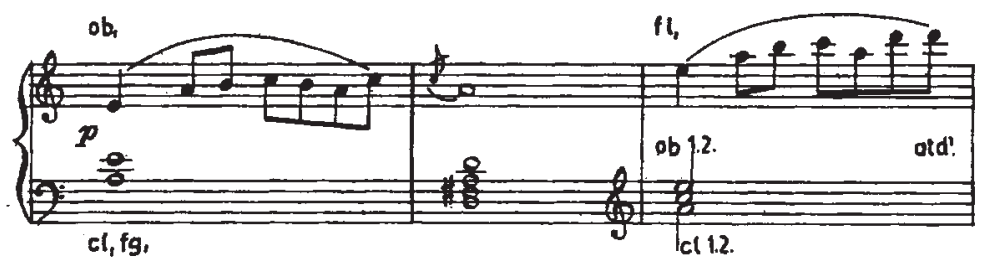

9 LEXMANN, Juraj. Hudobné ozvučenie Plickovho filmu Zem spieva (Adding Music to Plicka's Movie The Earth Sings). Slovenské divadlo, 27/2 (1979), p. 199-239, herep. 229. 
Very probably this tune is a variation of the song Ej zalužicki pol'o, although Plicka claims it is a song from the village Košecké Rovné. ${ }^{10}$

\section{Example 3}

Nápev č. 9

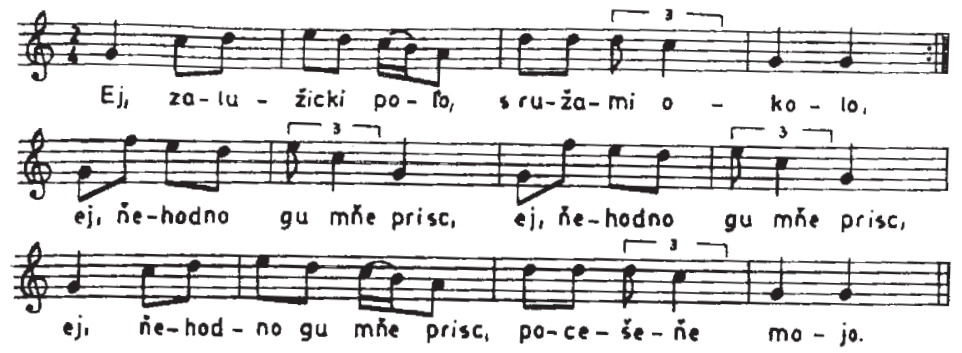

There is also quotation of the song Ej zalužicki pol'o, sung by the female Choir, where Plicka realized his own Ideal of folk-songs-singing - it is the tone brought into tune through portamento, which should give some kind of "pasivity“ to the singing and eliminate Pathos, which is connected with singing of artistic songs. In this concrete case we have to say, indeed, that it brings such singing closer to the tradition of Russian folk music and not much corresponds with the tradition of East-slovakian folk music.

Even the motif sounding at the beginning of the film is original (Journey through Slovakia) and it appears several times during the film - it works as a kind of leitmotif. In his endeavour to attain a certain "Slovak character" of the tune Škvor employs a descending melody with the fourth jump downwards in the conclusion for this motif (we have already mentioned the "pan-Slavic" character of this interval device).

\section{Example 4}

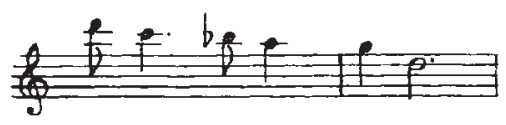

Generally we could say, that the composer succeded to create extraordinary concentrated and and well-balanced pattern, although it is composition in the form of suite - it was then normal praxis to compose a film music as a suite and to record relatively long parts (like Concert-numbers, rather than film loops as today is normal) on the film strip. Subsequently the Editor finalised the editing. It enabled technically very exact connection 
of sound and picture (not to mention, that in this case the Editor was very gifted artist - Alexander Hackenschmied). The pure Choice of musical material seems to be more sophisficated, as normally is expected by the film music - as Plicka alone prefer by the selection of the used music more artistic reasons instead of the ethnologic reality, similar the Composer Škvor prefers using of material, which can assign some level of affinity of character or in conception of melodic line (variations, inversion, a.s.o), what together with the used „leitmotifs" support the concentration of music from the formal whole. In this sense, the score „runs over“ the ambit of descriptive film music towards the technics of development known from so-called absolute music - beside the aforementioned „leitmotifs“ we can find here "scherzo-like“ passage - in the scene of market in $3 / 8$ metre, which is used here like contrast to dominating "pair" metres:

\section{Example 5}

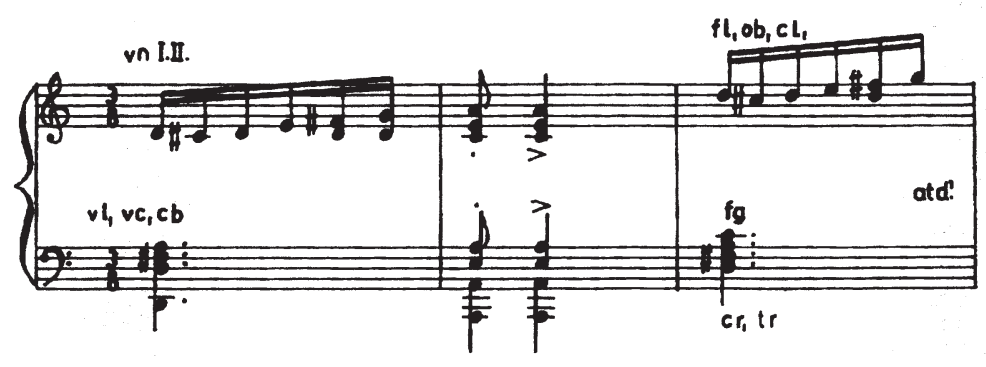

Anyway, Škvor demonstrate his real mastership in using of musical elements - the individual tunes, the characteristic and expressional nuancies in very suggestive mode support the pictures, definitely with an outstanding instrumentation.

The film The Earth Sings was relatively successful on the premiere at home (especially in Košice - in the city of 70000 inhabitants there was more than 14000 visitors - itis very interesting, if we remember, that the city was predominantly hungarian then, $\mathrm{f}$. e. in Prague the attendance was relatively weak - only 12000 visitors in the city of 850000 inhabitants), although there it was some meanings in Slovakia, that the film profanes Slovaks and Slovakia through the showing of backward and undeveloped life in slovakian village in contrary of modern czech metropole - Prague at the beginning of the film. Although the critics were extraordinarily good and the whole artistic society in Czechoslovakia accepted the film as an outstanding output of new Slovak cinematography, the yields from the entrance- fees were very low and by far did not cover the charges. Under this financial failure suffered above all Ladislav Kolda (his depts in height of about 200000 Kč paid until 1937). ${ }^{11}$

Apart from Czechoslovakia the film was shown in Austria, Switzerland, the Netherlands, France, Sweden, U.S.A. and Canada. And it won a prize at the Venice Biennale) Its

11 For more details see SLIVKA, Martin - LEXMANN, Juraj - LACKOVÁ, Sylvia. Karol Plicka vo filmovej faktografii. Bratislava: Slovenský filmový ústav, 1983, p. 69-91. 
qualities secured its place in the world cinematography, and Škvor's music substantially contributed to the success of the film. According to Plicka, Škvor's music influenced also the creation of the emerging generation of Slovak composers. Indeed, some indications of the association with Škvor's film score from 1932-1933 can be traced in the folklore ensembles' creation after 1948 (f. e. Music for the first Programm of SLUK, Op. 42, 1949 by A. Moyzes, and many others).

On the other side, it is difficult to agree with this opinion, as the overall sound of music refers mostly to the models from the Russian Romantic tradition, which was not longer truly current for the young generation of slovak composers as an Ideal and inspiration. As we have mentioned,the Creation of slovak national music became the main task for the following young generation of Slovak composers - A. Moyzes, E. Suchoň a J. Cikker (all these composers, similar to F. Škvor, were students of V. Novák). These composers saw the main inspiration in Western music tradition, specially in French impressionism connected with the tonality and melody of Slovak folk Song and relicts of german romanticism. They entrenched the style and the compositional look of new Slovak music which were accepted by both the critics and public, and for a long time became de facto the official doctrine of Slovak music. In this sense Škvor's music to Plicka's film is a significant, albeit singular example of the concentrated endeavour to create "Slovak" music possessing specific stylistic and idiomatic characteristics.

\section{Bibliography}

ELSCHEK, Oskár - ELSCHEKOVÁ, Alica. Úvod do štúdia slovenskej ludovej hudby. Bratislava, Hudobné centrum, 2005.

HRČKOVÁ, Nad’a. Tradícia, moderost’ a slovenská hudobná kultúra. Bratislava: Litera, 1996.

KRESÁNEK, Jozef. Slovenská l’udová pieseñ so stanoviska hudobného. Bratislava: Slovenská akadémia vied a umení, 1951.

LEXMANN, Juraj. Hudobné ozvučenie Plickovho filmu Zem spieva. Slovenské divadlo 27/2, 1979, p. 199-239.

LEXMANN, Juraj. Slovenská filmová hudba 1896-1996. Bratislava, Ústav hudobnej vedy SAV, ASCO Art\&Science, 1996.

SLIVKA, Martin - LEXMANN, Juraj - LACKOVÁ, Sylvia. Karol Plicka vo filmovej faktografii. Bratislava: Slovenský filmový ústav, 1983, p. 69-91.

URBANCOVÁ, Hana. Novouhorský štýl v slovenskej hudobnej kultúre a procesy sebaidentifikácie. In SLÁDEK, Kamil - Škvarna, Dušan (eds.). Hladanie novej podoby strednej Európy. Bratislava: Centrum pre európsku politiku, 2005, p. 221-231. 
